\title{
Study of serological prevalence of transfusion transmissible infections among blood donors in a tertiary care hospital in North India
}

\author{
Anita Omhare ${ }^{1}$, Neetu Purwar ${ }^{2}$, Sanjeev K Singh ${ }^{3, *}$, Ujma Rana ${ }^{4}$ \\ ${ }_{1,3}$ Assistant Professor, ${ }^{2}$ Lecturer, ${ }^{4}$ Laboratory Technician, Dept. of Pathlogy, ${ }^{1,2,4} \mathrm{GSVM}$ Medical College, Kanpur, Uttar Pradesh, \\ ${ }^{3}$ U.P. University of Medical Sciences, Saifai, Etawah, Uttar Pradesh, India
}

*Corresponding Author:

Email: drsanjeev.rml@gmail.com

Received: $5^{\text {th }}$ December, 2017

Accepted: $27^{\text {th }}$ December, 2017

\begin{abstract}
Introduction: Blood transfusion has been subjected to risk of transfusion transmissible infections such as HIV (Human Immunodeficiency Virus), HBV (Hepatitis B virus), HCV (Hepatitis C virus), syphilis etc. This risk has been reduced dramatically by routine screening of blood donors in blood banks.

Objective: Our aim was to study the serological prevalence of transfusion transmissible infections (TTI) among donors and to find any correlation between these infections and blood groups.

Methodology: This is a retrospective observational study for a period of one year (Dec 2014- Nov2015), and this study has been carried out in blood bank of tertiary care hospital of North India. Data of all voluntary and replacement donors retrieved from blood bank records i.e. ABO group, Rh type and results of serological tests performed.

Results: Total 27,689 donors were screened during the study period and 559 donors were found seropositive for transfusion transmissible infections (2.01\%). In which maximum 403 donors were positive for HBV (1.45\%), followed by 93 -HCV (0.33\%), 42-syphilis $(0.15 \%), 19$-HIV $(0.068 \%)$ and 2 for malaria antigen $(0.007 \%)$. Seropositive cases for HBV, HCV and MP antigen were maximum in blood group B positive $(\mathrm{B}+)$ donors. While seropositive cases for syphilis were more encountered in A positive blood group $(\mathrm{A}+)$. HIV prevalence seen more in $\mathrm{O}$ positive group $(\mathrm{O}+)$.

Conclusion:_In this study, serological prevalence among apparently healthy donors was $2.01 \%$. Which varies from $0.76 \%$ to $3 \%$ in different blood group donors. So strict screening is essential for all donors to prevent these life-threatening TTI. We observed no association between blood group antigens and these transfusion transmissible infections. So, more studies in larger level are required to find out any association.
\end{abstract}

Keywords: Blood donors, Transfusion transmissible infections, HBV, HCV, HIV, Blood group.

\section{Introduction}

Blood transfusion is associated with risk of life threatening infections like human immunodeficiency virus (HIV), Hepatitis B Virus (HBV), Hepatitis C Virus (HCV), Syphilis and Malaria Parasite (MP). These infections termed as transfusion transmissible infections (TTI). All TTI's are life threatening infections. However, risk of these infections has been reduced due to routine donor screening. ${ }^{1,2}$ Inadequately screened blood is the main cause of transfusion transmissible infections.

Red blood cells (RBC) have surface blood group antigens. Among many blood group systems, $\mathrm{ABO}$ and $\mathrm{Rh}$ blood groups system are the most important ${ }^{3}$. This has been observed that specific $\mathrm{ABO}$ blood group antigens are associated with the increase risk of some infections and malignancies. ${ }^{4}$

Present work has been conducted to study the serological prevalence of transfusion transmittable infections among blood donors in this region and to observe any association of blood groups to these infections.

\section{Materials and Methods}

This retrospective observational study had been conducted in blood bank of LLRM Hospital, associated with GSVM Medical College Kanpur. This is one of the largest blood bank in this region, in numbers of blood donations. Duration of study was one year (1 Dec 201430 Nov 2015). In this duration total 27689 apparently healthy donors were screened for Transfusion transmissible infections i.e. HBV, HCV, Syphilis, HIV and MP. Standard Criteria for the selection of donors had been followed. On the basis of detailed history, all professional donors, drug abusers, HIV risk individuals had been excluded. Proper implied consent had been taken in all cases.

Serological screening of all 27689 donors had been done for Hepatitis B surface antigen (HBsAg), Hepatitis C Virus antibodies (Anti-HCV), Human Immunodeficiency Virus antibodies-1,2 (anti-HIV 1,2), Treponema pallidum haemagglutination for syphilis (TPHA), and Malaria parasite antigen test (MP). All tests had been performed by using NACO (National AIDS control organisation) approved rapid kits and followed by third generation ELISA (Enzyme linked immunosorbent assay) supplied by Qualpro Diagnostics, Goa. Serological screening of malaria 
parasite (MP) was done by using ELISA for detection of malaria specific antigen $\mathrm{pLDH}$. (Qualisa Malaria)

\section{Results}

A total of 27689 blood donors had been screened for transfusion transmissible infections in our study. $\mathrm{ABO}$ blood group examination of donors revealed blood group "O" as most common blood group i.e. 10072 donors (36.37\%), followed by blood group "B" i.e. 9806 donors (35.41\%). Blood group "A" was seen in $4834(17.45 \%)$, while blood group "AB" was seen in $2977(10.75 \%)$. Bombay blood group was not seen in our study (Table-1).

Table 1: ABO blood group of donors

\begin{tabular}{|l|c|c|c|c|c|}
\hline S. No & $\begin{array}{c}\text { Blood } \\
\text { group }\end{array}$ & Rh D status & $\begin{array}{c}\text { Number of } \\
\text { donors }\end{array}$ & Percentage & Total (\%) \\
\hline 1 & $\mathrm{~A}$ & Positive & 4302 & $15.53 \%$ & \multirow{2}{*}{$4834(17.45 \%)$} \\
\cline { 3 - 5 } & & Negative & 532 & $1.92 \%$ & \\
\hline 2 & $\mathrm{~B}$ & Positive & 9358 & $33.79 \%$ & \multirow{2}{*}{$9806(35.41 \%)$} \\
\cline { 3 - 5 } & & Negative & 448 & $1.61 \%$ & \\
\hline 3 & $\mathrm{AB}$ & Positive & 2845 & $10.27 \%$ & \multirow{2}{*}{$2977(10.75 \%)$} \\
\cline { 3 - 5 } & & Negative & 132 & $0.47 \%$ & \\
\hline 4 & \multirow{2}{*}{$\mathrm{O}$} & Positive & 9416 & $34.0 \%$ & \multirow{2}{*}{$10072(36.37 \%)$} \\
\cline { 3 - 5 } & & Negative & 656 & $2.36 \%$ & \\
\hline \multicolumn{2}{|c|}{ Total } & 27689 & $100 \%$ & $27689(100 \%)$ \\
\hline
\end{tabular}

After RhD blood grouping analysis, we found 25921 donors (93.61\%) were $\mathrm{RhD}$ positive, while 1768 $(6.38 \%)$ were $\mathrm{RhD}$ negative (Table 2 )

Table 2: Rh D status among donors

\begin{tabular}{|c|l|c|}
\hline S. No. & Rh D status & $\begin{array}{c}\text { Number of } \\
\text { donors (\%) }\end{array}$ \\
\hline 1 & Positive & $25921(93.6 \%)$ \\
\hline 2 & Negative & $1768(6.38 \%)$ \\
\hline \multicolumn{2}{|c|}{ Total } & $27689(100 \%)$ \\
\hline
\end{tabular}

In this study, total 559 donors out of total 27689 , were found seropositive for transfusion transmissible infections. So, prevalence was $2.01 \%$ (559/27689). Among seropositive cases maximum cases i.e. 403
(1.45\%) were of HBV infection, followed by 93 $(0.33 \%)$ cases of $\mathrm{HCV}, 42(0.15 \%)$ of syphilis, 19 $(0.068 \%)$ of HIV, and $2(0.007 \%)$ of MP antigen. HBsAg (HBV infection) were positive maximum in $\mathrm{B}+$ blood group i.e. 161/403 (39.95\%) followed by O+ $(22.58 \%) \& \mathrm{~A}+(22.33 \%)$. We also found highest seropositivity for Anti-HCV (HCV infection) in $\mathrm{B}+$ blood group i.e. 33/93 (35.48\%), followed by O+ (27.95\%). Among syphilis positive donors $33.33 \%$ were of A+ blood group, $28.57 \%$ of B+ blood group. In HIV positive donors, 7 out of 19 were $\mathrm{O}+(36.84 \%)$, followed by $\mathrm{B}+(31.57 \%)$. Blood group of two MP positive donors was $\mathrm{B}+$. (Table 3 )

Table 3: Transfusion transmitted infections positivity according to blood group

\begin{tabular}{|l|c|c|c|c|c|c|}
\hline Blood group & $\begin{array}{c}\text { HBsAg+ donors } \\
(\boldsymbol{\%})\end{array}$ & $\begin{array}{c}\text { Anti-HCV+ } \\
\text { donors }(\boldsymbol{\%})\end{array}$ & $\begin{array}{c}\text { Syphilis+ } \\
\text { donors (\%) }\end{array}$ & $\begin{array}{c}\text { HIV+ } \\
\text { donors }(\%)\end{array}$ & $\begin{array}{c}\text { MP } \\
\text { antigen+ } \\
\text { donors }(\boldsymbol{\%})\end{array}$ & $\begin{array}{c}\text { Total seropositive } \\
\text { cases/total donors } \\
(\%)\end{array}$ \\
\hline A Positive & $90(22.33 \%)$ & $15(16.12 \%)$ & $14(33.33 \%)$ & $2(10.52 \%)$ & 0 & $121 / 4302(2.81 \%)$ \\
\hline A Negative & $5(1.24 \%)$ & $2(1.24 \%)$ & 0 & 0 & 0 & $7 / 532(1.31 \%)$ \\
\hline B Positive & $161(39.95 \%)$ & $33(35.48 \%)$ & $12(28.57 \%)$ & $6(31.57 \%)$ & $2(100 \%)$ & $214 / 9358(2.28 \%)$ \\
\hline B Negative & $7(1.73 \%)$ & $1(1.07 \%)$ & $1(2.38 \%)$ & 0 & 0 & $9 / 448(2 \%)$ \\
\hline AB Positive & $45(11.16 \%)$ & $12(12.90 \%)$ & $5(11.90 \%)$ & $4(21.05 \%)$ & 0 & $66 / 2845(2.31 \%)$ \\
\hline AB Negative & 0 & $4(4.30 \%)$ & 0 & 0 & 0 & $4 / 132(3 \%)$ \\
\hline O Positive & $91(22.58 \%)$ & $26(27.95 \%)$ & $9(21.42 \%)$ & $7(36.84 \%)$ & 0 & $133 / 9416(1.41 \%)$ \\
\hline O Negative & $4(0.99 \%)$ & 0 & $1(2.38 \%)$ & 0 & 0 & $5 / 656(0.76 \%)$ \\
\hline Total & $403(100 \%)$ & $93(100 \%)$ & $42(100 \%)$ & $19(100 \%)$ & $2(100 \%)$ & $559 / 27689(2.01 \%)$ \\
\hline
\end{tabular}

Among specific blood groups, serum prevalence of TTI were more in A positive $(2.81 \%)$, B Positive (2.28\%), $\mathrm{AB}$ positive (2.31\%) and $\mathrm{AB}$ negative (3\%), if we compare with total serum prevalence $(2.01 \%)$.
Serum prevalence of TTI were low in $\mathrm{O}$ negative $(0.76 \%)$, O positive $(1.41 \%)$, A negative $(1.31 \%) \& \mathrm{~B}$ negative $(2 \%)$. 


\section{Discussion}

Unsafe Blood transfusion is associated with risk of infections termed as transfusion transmissible infections (TTI). Strict screening of all blood donors is essential to ensure safe supply of blood and its components. Blood from unsafe blood donors can cause transmission of life threatening infections like HIV-AIDS, HBV, HCV, Syphilis and Malaria. Studies indicate that professional donors represent a high-risk group of HIV infection ${ }^{5}$. Such donors are supposed to associated with significantly high prevalence of TTI $^{6}$ Pre-blood donation counselling is very important. In a study, author reported that out of 113 seropositive donors studied, nearly $50 \%$ of them were aware of their seropositive status. ${ }^{7}$ Such donations can be avoided by proper pre-blood donation counselling.

In our study we observed $2.01 \%$ serological prevalence of TTI in apparently healthy voluntary/replacement donors. Among seropositive cases maximum serum prevalence was of $\mathrm{HBV}$ infection $(1.45 \%)$, followed by HCV $(0.33 \%)$, syphilis $(0.15 \%)$, HIV $(0.068 \%)$ and MP $(0.007 \%)$. Many of the similar Indian studies show prevalence rates of HBV $1.2-3.5 \%$, HCV 0.12-4\%, HIV 0.51-3.87\% and Syphilis $0.3-0.82 \% .^{8-11}$ Our results are also similar except very low prevalence of HIV. A very low prevalence of HIV can be attributed to strict pre-donation counselling and exclusion of high risk individuals as well as low prevalence in the region.

Few diseases have shown their association with blood groups e.g. peptic ulcer, gastric carcinoma, erythroblastosis fetalis, coronary artery disease etc. one study showed the protection against infectious diseases from inheritance of polymorphism in genes encoding and regulating the expression of $\mathrm{ABO}$ blood group antigens in bodily secretions. ${ }^{12}$

Some blood types may be associated with inheritance of other diseases e.g. the Kell antigen is sometimes associated with McLeod syndrome ${ }^{13}$. Some blood types may affect susceptibility to infections e.g. resistance to specific malaria species seen in individuals lacking the Duffy antigen. ${ }^{14}$

Das et al observed that frequency of HBV and $\mathrm{HCV}$ infection showed maximum association with $\mathrm{O}$ positive blood group (49.8\% and $61.1 \%$ respectively) ${ }^{\mathbf{1 5}}$. Behal et al observed higher prevalence of HBV infection in blood group B (38.7\%), they assumed that could be due to higher prevalence of B blood group in their area. ${ }^{16}$ Sreedhar Babu KV et al stated maximum association of $\mathrm{HBV}$ and $\mathrm{HCV}$ infection with $\mathrm{O}$ blood group constituting 39\% and $34.5 \%$ respectively. They also found similar prevalence of $\mathrm{HBV}$ in $\mathrm{RhD}+$ and RhD- $(2.4$ and $2.1 \%) .{ }^{17}$ There was no statistically significant difference between the two observations. Tyagi et al observed that the negative blood groups are more prone to TTIs, and donors with A negative blood group are more affected with HBV infection, while $\mathrm{B}$ negative donors with $\mathrm{HCV}$ infection. ${ }^{18}$ Omar et al reported that seroprevalence of $\mathrm{HBV}, \mathrm{HCV}$ infection higher among blood group $\mathrm{O}$ donors and lowest in $\mathrm{AB}$ group. While in $\mathrm{Rh}$ group, these infections were higher in $\mathrm{Rh}+$ donors. ${ }^{19}$

In our study, we observed that HBV and HCV infection were associated maximum with $\mathrm{B}$ positive blood group (39.95\% and $35.48 \%$ respectively). While we found $\mathrm{Rh}+$ blood group more associated with $\mathrm{HBV}$ infection than $\mathrm{Rh}$ negative group i.e. $1.49 \%$ (387/25921) and 0.9\% (16/1768) respectively.

Kumar and co-workers reported that the highest prevalence of HIV and HBV infection were found in blood group $\mathrm{O}+$ donors. ${ }^{20}$ In a study conducted in Karnataka India, A. Banu reported that $\mathrm{O}$ positive was the most prevalent blood group in both adults $(40.13 \%)$ and paediatric $(43.33 \%)$ HIV seropositives. ${ }^{21}$ Similar result is seen in our study, where HIV positivity was highest in $\mathrm{O}+$ donors $(36.84 \%$ ) followed by $\mathrm{B}+$ donors. In a similar study conducted in north India, Hassan MJ et al also reported highest seroprevalence of $\mathrm{HBsAg}$ (1.7\%) among TTI, followed by HCV (0.74\%), HIV $(0.33 \%)$ and syphilis $(0.16 \%){ }^{22}$

\section{Conclusion}

In this study we found significant serological prevalence $(2.01 \%)$ of TTI in apparently healthy donors. Which varies from $0.76 \%$ to $3 \%$ in different blood group donors. So strict screening is essential for all donors to prevent these life-threatening TTI. We also conclude that control measures should be taken like education, vaccination (HBV), counselling of high risk group of blood donors to limit the prevalence of TTI. We observed no association of these TTI with $\mathrm{ABO}$ and Rh blood groups. However similar large-scale studies are required to find out any association.

\section{References}

1. Allain JP, Thomas I, Sauleda S. Nucleic acid testing for emerging viral infections. Transfus Med. 2002;12:275-83.

2. Luban NL. Transfusion safety: where are we today? Ann N Y Acad Sci. 2005;1054:325-41.

3. Mollison PL. The genetic basis of $\mathrm{Rh}$ blood group system. Transfusion. 1994;34:539-41.

4. Greenwell P. Blood group antigens: molecules seeking a function? Glycoconjugate 1997;14:159-73.

5. Chattopadhya D, Riley LW, Kumari S. Behavioural risk factors for acquisition of HIV infection and knowledge about AIDS among male professional donors in Delhi. Bull World Health Organ. 1991;69:319-23.

6. WHO. Blood Transfusion Safety: Voluntary nonremunerated blood donation. 2011.

7. Latha B. Abstract of $37^{\text {th }}$ Annual Conference of Indian Society of Blood Transfusion and Immunohematology (ISBTI). Asian J Transfus Sci. 2011;5:63-109.

8. Garg S, Mathur DR, Garg DK. Comparison of seropositivity of HIV, HBV, HCV and syphilis in replacement and voluntary blood donors in wesrern india. Indian J Pathol Microbiol. 2001;44:409-12. 
9. Singh B, Verma M, Verma K. Markers for transfusion associated hepatitis in north indian blood donors: prevalence and trends. Jpn J Infect Dis. 2004;57:49-51.

10. Srikrishna A, Sitalaxmi S, Prerna Damodar S. How safe are our safe donors? Indian J Pathol Microbiol. 1999; 42:411-6.

11. Ekadashi R, Langer S. Seroprevalence of Human Immunodeficiency Virus and syphilis in blood donors of Delhi. Indian J Med Microbiol. 2009;27:167-8.

12. Anstee DJ. The relationship between blood groups and disease. Blood. 2010;115:4635-43.

13. Chown B, Lewis M, Kaita K. A new Kell blood group phenotype. Nature. 1957;180:711.

14. Miller LH, Mason SJ, Clyde DF, McGinniss MH. The resistance factor to plasmodium vivax in blacks. The Duffy-blood-group genotype, FyFy. N Engl J Med. 1976;295:302-4.

15. Das S, Kumar MLH. Association ofblood group typesto hepatitis B and hepatitis $\mathrm{C}$ virus infection among blood donors: a five-year institutional based study. Int J Basic Appl Med Sci. 2012;2:191-5.

16. Behal R, Jain R, Behal KK, Bhagoliwal A et al. Seroprevalence and risk factors for hepatitis B virus infection among general population in northern India. Arq Gastroenterol. 2008;45:137-40.

17. Sreedhar Babu KV et al. Association of $\mathrm{ABO}$ and $\mathrm{Rh}$ blood groups to $\mathrm{HBV}, \mathrm{HCV}$ infections among blood donors in a blood bank of tertiary care teaching hospital in southern India: a retrospective study. Int J Res Med Sci. 2015;3:1672-6.

18. Tyagi S, Tyagi A. Possible correlation of transfusion transmitted diseases with Rh type and $\mathrm{ABO}$ blood group system. Journal of clinical and diagnostic research. 2013;7:1930-1

19. Omar AAA, Al-Hayan NN, Mohammed MJ. The infection with HBV and HCV and their relationship to $\mathrm{ABO}$ blood group among blood donors. J Fac Med Baghdad. 2012;54:52-5.

20. Kumar MR, Rao MS, Pulicherla KK, Ghosh M et al. Studies on the distribution of hepatitis B (HBV) and human immunodeficiency virus (HIV)- their relation to the blood groups and rhesus (Rh) factor in Guntur district of Andhra Pradesh, India. Asian J Pharm Clin Res. 2013;6:109-11.

21. Banu A, Ahmed SM, Shastri S. Distribution of ABO and $\mathrm{Rh}$ blood groups in HIV seropositives at an integrated counselling and testing centre in Karnataka, India. SAARCTB. 2011;8:42-5.

22. Hassan MJ, Khan S, Jairaipuri ZS, Rana S et al. Seroprevalence of Transfusion transmitted infections by using $4^{\text {th }}$ generation Enzyme-linked immunosorbent assay kit: A 3 year study in a tertiary health care centre of Delhi. Annals of Pathology and Laboratory Medicine. 2016;3(4):A333-9. 